\title{
Expression of RHAMM/CD168 and other tumor-associated antigens in patients with B-cell chronic lymphocytic leukemia
}

\author{
K. GIANNOPOULOS ${ }^{1,3}$, L. LI ${ }^{1}$, A. BOJARSKA-JUNAK ${ }^{3}$, J. ROLINSKI ${ }^{3}$, A. DMOSZYNSKA ${ }^{2}$,

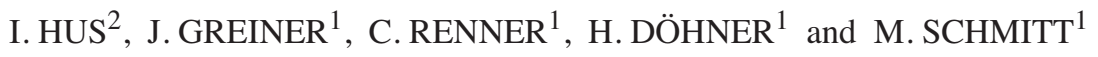 \\ ${ }^{1}$ Department of Internal Medicine III, University of Ulm, D-89081 Ulm, Germany; Departments of ${ }^{2}$ Hematooncology, \\ and ${ }^{3}$ Clinical Immunology, Medical University of Lublin, 20-950 Lublin, Poland
}

Received January 18, 2006; Accepted March 17, 2006

\begin{abstract}
Antigen targeted immunotherapies might represent a novel treatment for B-cell chronic lymphocytic leukemia (B-CLL). We screened the mRNA expression of tumorassociated antigens (TAAs) from the literature (fibromodulin, survivin, OFA-iLRP, BAGE, G250, MAGE1, PRAME, proteinase, syntaxin, hTERT, WT-1) and TAAs defined previously by serological analysis of cDNA expression libraries from leukemic cells (PINCH, HSJ2, MAZ, MPP11, RHAMM/CD168, NY-Ren60). Peripheral blood mononuclear cells from 43 B-CLL patients and 20 healthy volunteers (HVs) were examined by conventional and quantitative RT-PCR. mRNA of RHAMM/CD168, fibromodulin, syntaxin and NYRen60 was expressed in 55-90\%, and mRNA of HSJ2, MAZ and OFAiLRP was expressed in $90-100 \%$ of the patients. No expression of WT-1, hTERT, BAGE, G250, MAGE1 or survivin was observed. Low (2-20\%) expression frequencies of MPP11, PINCH, PRAME and proteinase were detected. RHAMM/CD168, fibromodulin, PRAME and MPP11 showed expression in B-CLL patients, but not in HVs. Because of the exquisite tissue expression of RHAMM/CD168 and its high expression frequency in CLL patients, mixed lymphocyte peptide culture (MLPC), enzyme-linked immunosorbent spot (ELISPOT) and flow cytometry were performed for antigen specific T-cells. In MLPC, RHAMM specific responses by CD8 ${ }^{+}$HLA-A2/R3tetramer+CCR7-CD45RA ${ }^{\text {high }}$ effector T-cells were detected. RHAMM/CD168 might be a possible target for future immunotherapies in both ZAP-70(+) and ZAP-70(-) B-CLL patients.
\end{abstract}

Correspondence to: Dr Michael Schmitt, Department of Internal Medicine III, University of Ulm, Robert-Koch-Str. 8, D-89081 Ulm, Germany

E-mail: michael.schmitt@uniklinik-ulm.de

Key words: B-cell chronic lymphocytic leukemia, tumor-associated antigens, leukemia-associated antigens, cytotoxic T lymphocytes, receptor for hyaluronic acid mediated motility

\section{Introduction}

B-cell chronic lymphocytic leukemia (B-CLL) is the most common leukemia in Western countries (1). The disease is often characterized by a long natural course, thus opening a time window for cellular immunotherapies (1).

For the development of T-cell based therapies, the definition of immunogenic tumor-associated antigens (TAAs), which are expressed in malignant cells from leukemia/cancer patients but not in tissues of healthy volunteers, constitutes a cornerstone (2).

Generating specific immune responses by cytotoxic $\mathrm{T}$ lymphocytes (CTLs) against B-CLL cells might be cumbersome, as B-CLL patients suffer from increasing immunosuppression with the progression of the disease $(3,4)$. T-cell function as well as antigen presentation by dendritic cells (DC) were reported to be impaired in B-CLL $(5,6)$. However, CTL responses against modified immunoglobulin derived peptides and tumor-derived RNA have been generated in B-CLL patients $(7,8)$. The graft versus leukemia $(\mathrm{GvL})$ reaction observed after allogeneic stem cell transplantation or donor lymphocyte infusions (DLIs) suggests the existence of immunogenic antigens in leukemias $(9,10)$. Several immunogenic antigens are shared by different types of cancer and leukemia $(11,12)$.

To identify good candidate targets for immune therapies for patients with B-CLL, the following immunogenic TAAs known from the literature and from our own serological analysis of recombinant tumor cDNA expression libraries (SEREX) prepared from leukemic cells were investigated: the preferentially expressed antigen in melanoma (PRAME), Wilms tumor gene 1 (WT-1), carboanhydrase 9 (CA9/G250), survivin, proteinase $3, \mathrm{G} 250$, and telomerase catalytic subunit (hTERT) (12-18). Recently, fibromodulin and the oncofetal antigen immature laminin-receptor protein (OFAiLRP) have been characterized as TAAs in B-CLL with the potential to elicit specific anti-tumor response $(19,20)$. The receptor for hyaluronic acid mediated motility (RHAMM/CD168) and the M-phase phosphoprotein 11 (MPP11), two TAAs identified by our group using the SEREX technique, showed tumorspecific humoral immune responses and tumor-restricted mRNA expression in patients with acute myeloid leukemia (AML) and chronic myeloid leukemia (CML) $(11,12)$. Further 
Table I. Clinical characteristics of 43 B-CLL patients.

\begin{tabular}{|c|c|c|c|c|c|c|c|c|c|}
\hline $\begin{array}{l}\text { Pts. } \\
\text { no. }\end{array}$ & $\begin{array}{l}\text { Sex/ } \\
\text { age }\end{array}$ & $\begin{array}{c}\text { Rai } \\
\text { stage }\end{array}$ & $\begin{array}{c}\text { WBC }(\mathrm{G} / \mathrm{l}) / \\
\text { lymphocytes } \\
(\%)\end{array}$ & $\begin{array}{l}\text { Doubling } \\
\text { time } \\
\text { (months) }\end{array}$ & $\begin{array}{l}\mathrm{Hb} \\
(\mathrm{g} / \mathrm{l})\end{array}$ & $\begin{array}{l}\text { Platelet } \\
\text { count } \\
(\mathrm{G} / \mathrm{l})\end{array}$ & $\begin{array}{c}\text { ZAP-70 } \\
\text { expression } \\
\left(\% \text { on } \mathrm{CD} 5 / 19^{+} \text {cells }\right)\end{array}$ & $\begin{array}{c}\text { CD38/ } \\
\text { CD19 } \\
(\%)\end{array}$ & $\begin{array}{c}\text { T-cell } \\
\text { assays } \\
\text { performed }\end{array}$ \\
\hline 1 & $\mathrm{~F} / 57$ & 2 & $75 / 85$ & 20 & 140 & 220 & 4.62 & 1.85 & n.d. \\
\hline 2 & $\mathrm{M} / 58$ & 3 & $25.7 / 58$ & n.a. & 107 & 106 & n.a. & n.a. & n.d. \\
\hline 3 & $\mathrm{M} / 69$ & 1 & $35 / 75$ & 3 & 154 & 188 & 27.26 & 10.21 & ELISPOT \\
\hline 4 & $\mathrm{M} / 53$ & 0 & $61.1 / 90.3$ & 12 & 150 & 211 & n.a. & n.a. & n.d. \\
\hline 5 & $\mathrm{M} / 74$ & 0 & 79/76 & n.a. & 139 & 207 & n.a. & n.a. & n.d. \\
\hline 6 & $\mathrm{M} / 67$ & 0 & $26.3 / 76$ & $>18$ & 145 & 223 & n.a. & n.a. & n.d. \\
\hline 7 & $\mathrm{M} / 71$ & 2 & $187 / 93$ & 1 & 120 & 160 & 4.87 & 28.04 & n.d. \\
\hline 8 & $\mathrm{M} / 65$ & 3 & $118 / 86$ & 4 & 107 & 177 & 6.71 & 0.19 & n.d. \\
\hline 9 & $\mathrm{M} / 58$ & 2 & $288 / 67$ & 2 & 108 & 196 & 28.37 & 21.82 & n.d. \\
\hline 10 & $\mathrm{M} / 63$ & 4 & $88 / 88$ & 1 & 156 & 39 & 38.09 & 2.33 & n.d. \\
\hline 11 & $\mathrm{M} / 71$ & 3 & $260 / 88$ & 0.5 & 102 & 160 & 26.40 & 38.99 & n.d. \\
\hline 12 & $\mathrm{~F} / 51$ & 0 & $26.5 / 71.4$ & 20 & 142 & 227 & 15.88 & 26.67 & n.d. \\
\hline 13 & $\mathrm{M} / 57$ & 2 & $93.6 / 95$ & 4 & 169 & 233 & 60.07 & 25.34 & n.d. \\
\hline 14 & $\mathrm{M} / 74$ & 3 & $83.3 / 75$ & n.a. & 110 & 131 & 7.78 & 8.43 & n.d. \\
\hline 15 & $\mathrm{M} / 52$ & 2 & $96.1 / 87$ & n.a. & 149 & 167 & 49.05 & 29.93 & n.d. \\
\hline 16 & $\mathrm{M} / 68$ & 0 & $245 / 64$ & n.a. & 119 & 196 & n.a. & n.a. & n.d. \\
\hline 17 & $\mathrm{M} / 68$ & 4 & $17.6 / 94$ & n.a. & 97 & 17 & 47.52 & 9.41 & n.d. \\
\hline 18 & $\mathrm{M} / 53$ & 4 & $295 / 79$ & 1 & 94 & 24 & 29.15 & 38.07 & n.d. \\
\hline 19 & $\mathrm{~F} / 58$ & 0 & $49.5 / 71$ & 58 & 137 & 179 & n.a. & n.a. & n.d. \\
\hline 20 & $\mathrm{M} / 72$ & 0 & $14.4 / 62.1$ & $>38$ & 138 & 214 & 23.90 & 18.57 & n.d. \\
\hline 21 & $\mathrm{M} / 78$ & 0 & $16.6 / 63.3$ & $>54$ & 133 & 166 & 39.90 & 30.74 & n.d. \\
\hline 22 & $\mathrm{M} / 72$ & 0 & $26.6 / 75$ & 15 & 126 & 228 & 32.55 & 45.12 & n.d. \\
\hline 23 & $\mathrm{M} / 71$ & 0 & $24.9 / 75.2$ & $>26$ & 145 & 209 & 2.0 & 2.11 & n.d. \\
\hline 24 & $\mathrm{M} / 50$ & 0 & $16.4 / 75.8$ & 21 & 135 & 150 & 33.64 & 17.42 & n.d. \\
\hline 25 & $\mathrm{~F} / 73$ & 1 & $39.7 / 85.5$ & $>38$ & 139 & 179 & 19.10 & 21.46 & n.d. \\
\hline 26 & $\mathrm{~F} / 58$ & 1 & $49.6 / 76$ & 6 & 119 & 215 & n.a. & n.a. & n.d. \\
\hline 27 & $\mathrm{~F} / 53$ & 1 & $68.1 / 84.8$ & 11 & 115 & 169 & 2.63 & 12.27 & ELISPOT \\
\hline 28 & $\mathrm{~F} / 57$ & 1 & $42.6 / 86$ & 17 & 124 & 128 & 3.06 & 2.76 & n.d. \\
\hline 29 & $\mathrm{M} / 72$ & 1 & $66.5 / 83.3$ & 21 & 126 & 137 & 22.70 & 6.26 & ELISPOT \\
\hline 30 & $\mathrm{M} / 50$ & 0 & $45 / 86$ & $>12$ & 144 & 183 & 12.70 & 2.64 & ELISPOT \\
\hline 31 & $\mathrm{M} / 50$ & 0 & $24.8 / 85.3$ & $>12$ & 156 & 228 & 44.34 & 29.26 & ELISPOT \\
\hline 32 & $\mathrm{M} / 71$ & 1 & $96.2 / 80$ & $>12$ & 141 & 103 & 12.9 & 7.64 & n.d. \\
\hline 33 & $\mathrm{M} / 53$ & 1 & $51.9 / 75.6$ & n.a. & 126 & 131 & 15.77 & 20.66 & n.d. \\
\hline 34 & $\mathrm{M} / 78$ & 1 & $16.8 / 64.6$ & $>12$ & 142 & 142 & 13.36 & 18.55 & ELISPOT \\
\hline 35 & $\mathrm{M} / 71$ & 0 & $26.6 / 88$ & $>12$ & 135 & 165 & 7.51 & 9.5 & n.d. \\
\hline 36 & $\mathrm{~F} / 47$ & 0 & $16.6 / 87.2$ & 8 & 137 & 241 & 63 & 21.6 & n.d. \\
\hline 37 & $\mathrm{M} / 62$ & 1 & $40.9 / 77$ & $>12$ & 147 & 149 & 4.2 & 10.52 & ELISPOT \\
\hline 38 & $\mathrm{M} / 68$ & 1 & $53.8 / 85.4$ & n.a. & 128 & 236 & n.a. & 2.5 & ELISPOT \\
\hline 39 & $\mathrm{~F} / 73$ & 0 & $14.5 / 71.1$ & n.a. & 118 & 165 & 23.34 & 12.29 & ELISPOT \\
\hline 40 & $\mathrm{M} / 56$ & 1 & $23.4 / 61.9$ & $>12$ & 137 & 174 & n.a. & 10.21 & Tetramer \\
\hline 41 & $\mathrm{M} / 58$ & 1 & $38.7 / 75.4$ & $>12$ & 123 & 265 & 15.51 & 6 & Tetramer \\
\hline 42 & $\mathrm{M} / 72$ & 1 & $24.3 / 73$ & $>12$ & 104 & 308 & 6.04 & 5.07 & ELISPOT \\
\hline 43 & $\mathrm{~F} / 62$ & 0 & $17.2 / 62.2$ & 5 & 110 & 199 & 6.58 & 4.06 & Tetramer \\
\hline
\end{tabular}

n.a., not available; n.d., not done, i.e. no T-cell assays were performed.

TAAs previously defined by the SEREX analysis of AML/ CML patients by our group, such as the particularly interesting new Cys-His protein (PINCH), the heat shock protein (HSJ2) and the myc-associated zinc-finger protein (MAZ) $(12,21)$, or by others, such as the renal cell cancer antigen (NY-Ren60) (22), were examined.
In this study, the mRNA expression of all above mentioned TAAs was assessed by conventional RT-PCR assays in peripheral blood mononuclear cells (PBMCs) from B-CLL patients. Because of the exquisite expression pattern of RHAMM/ CD168 in normal tissues (expression only in testis, placenta and thymus) (11) and its high frequent appearance, even in 
patients with early stages of disease, quantitative RT-PCR and mixed lymphocyte peptide cultures followed by enzymelinked immunosorbent spot (ELISPOT) and flow cytometry assays were employed to assess the expression level and the immunogenicity of this novel leukemic antigen in B-CLL patients.

\section{Materials and methods}

Cell samples. Samples were taken at the time of diagnosis from 43 B-CLL patients treated in the Department of Hematooncology, Medical University of Lublin (Poland) in the framework of clinical B-CLL study protocols approved by the local ethics committee and peripheral blood samples were taken from the 20 healthy volunteers (HVs; age: 25-75 years, 10 males and females each) at the German Red Cross Blood Center, Ulm (Germany). Informed consent was obtained from all patients and healthy volunteer blood donors with respect to the use of their blood for scientific purposes. The clinical characteristics of the patients in this study are summarized in Table I. All patients had $>85 \%$ of B-CLL cells in their PBMC. No autoimmune effects like autoimmune hemolytic anemia or idiopathic thrombocytopenia were observed in the patients included in this study. Until inclusion in this study, none of the patients had been treated for their B-CLL.

Culture of cell lines. The human cell lines were cultured in a standard medium consisting of RPMI-1640 (Biochrom, Berlin, Germany) supplemented with $10 \%$ (v/v) AB serum, $2 \mathrm{mM}$ L-glutamine, 100 units/ml penicillin and 100 units $/ \mathrm{ml}$ streptomycin. T2-cells and the K562 cell line were obtained from the 'Deutsche Sammlung von Zellen und Mikroorganismen' (DSZM, Braunschweig, Germany).

Cell isolation. PBMCs were isolated by Ficoll density gradient centrifugation. The viability of obtained PBMCs was always $>95 \%$, as determined by trypan blue staining. The viable cells were quantified in a Neubauer chamber (Zeiss, Oberkochen, Germany) and stored for RNA preparation in liquid nitrogen.

Analysis of $\zeta$ associated protein-70 (ZAP-70) expression on $B$-CLL cells by flow cytometry. Analysis of ZAP-70 expression was performed as described previously (23). Briefly, 1x10 PBMCs were stained with monoclonal antibodies, CD19PE, CD5CyChrome or CD3PE (all from Caltag Laboratories, Burlingame, USA). Following membrane staining, the cells were fixed and permeabilized for $1 \mathrm{~h}$. After washing, antiZAP-70 antibody (Biomol Research Laboratories, Plymouth Meeting, USA), labeled by Zenon mouse IgG labeling reagent (Molecular Probes, Eugene, USA), was added to the sample tubes. Ten thousand events were acquired and analyzed using FACSCalibur (Becton-Dickinson, Franklin Lakes, USA) and CellQuest software (Becton-Dickinson). The cut-off level for ZAP positivity was set at $20 \%$, as with other studies (24).

$m R N A$ preparation and reverse transcription. For the isolation of mRNA from PBMCs, the $\mu$ MACS mRNA isolation kit (Miltenyi Biotec, Bergisch Gladbach, Germany) was used according to the manufacturer's instructions. Fifty ng of mRNA was reverse transcribed into $20 \mu \mathrm{l}$ of cDNA using a first-strand cDNA synthesis kit for RT-PCR (AMV) (Roche Diagnostics,
Mannheim, Germany). For each conventional RT-PCR and for each quantitative RT-PCR, $1 \mu \mathrm{l}$ of the cDNA preparation was used.

Reverse transcriptase-polymerase chain reaction (RT-PCR) of $T A A s$. The pattern of expression was assessed in samples from 30 B-CLL patients (Table I, patients 1-30) and 20 HV. ß-actin was used as a housekeeping gene. The expression of the genes of interest was assessed by RT-PCR and classified into one of the two groups: positive, detectable mRNA expression of the antigen; or negative, no detectable mRNA expression of the gene of interest. The mRNA isolated from K562 cells tested positive for all genes and therefore served as a positive control. Distilled water (DW) was used as a negative control. False positive results as a consequence of genomic DNA contamination were excluded by the design of primers located in different exons. The sequence of the primers for RT-PCR, temperatures of denaturation, annealing and elongation and the cycle numbers are shown in Table II. Products of two bands appeared as a result of RT-PCR and were observed in all positive for RHAMM/RHAMM-exon ${ }^{4} \mathrm{~B}$-CLL cases.

Quantitative 'real-time' reverse transcriptase-polymerase chain reaction ( $q R T-P C R)$ for RHAMM. For the quantitative measurement of the mRNA expression of RHAMM, quantitative real-time RT-PCR was performed using LightCycler SYBR-Green I technology according to the manufacturer's protocol (Roche Diagnostics) (21). The TATA-box binding protein (TBP) was used as a housekeeping gene. An initial denaturation step at $95^{\circ} \mathrm{C}$ for $10 \mathrm{~min}$ was followed by 40 cycles of $10 \mathrm{sec}$ at $95^{\circ} \mathrm{C}, 15 \mathrm{sec}$ at $62^{\circ} \mathrm{C}, 20 \mathrm{sec}$ at $72^{\circ} \mathrm{C}$ for the TBP. For RHAMM (Table II), an initial denaturation step at $95^{\circ} \mathrm{C}$ for $10 \mathrm{~min}$ was followed by 45 cycles of $10 \mathrm{sec}$ at $95^{\circ} \mathrm{C}$, $10 \mathrm{sec}$ at $66^{\circ} \mathrm{C}, 12 \mathrm{sec}$ at $72^{\circ} \mathrm{C}$. One $\mu 1$ of cDNA was used per qRT-PCR. To quantify the mRNA expression of RHAMM, a conventional PCR for RHAMM from K562 was performed and the amount of product cDNA was measured by photometry. A serial dilution of CDNA was subjected to PCR to obtain standard curves. The amounts obtained by quantitative measurement of mRNA (ag) for RHAMM and TBP were calculated into copy numbers and normalized to the housekeeping gene TBP, of which hitherto no retropseudogenes are known. Quantitative measurement of mRNA by real-time RT-PCR for RHAMM was performed for a cohort of 24 patients with B-CLLs in early stages $0-1$ according to the Rai classification (Table I, patients 20-43).

RHAMM/CD168-derived peptide. RHAMM/CD168-derived peptide sequences with HLA-A*0201-binding motifs were predicted using two different computer algorithms based on known binding affinities (25). RHAMM peptide R3 (pos. 165-173: ILSLELMKL) was chosen because it targets the most immunogenic RHAMM peptide in AML, CML and HV (26). The influenza matrix protein (IMP) derived peptide (GILGFVFTL) served as a positive control (15). Peptides were synthesized by Thermo Electron Corp. (Ulm, Germany) to a minimum of $95 \%$ purity as measured by high performance liquid chromatography.

Mixed lymphocyte peptide culture (MLPC). PBMCs from HLA-A2-positive B-CLL patients in an early stage of disease 
Table II. Primer sequences and PCR conditions for the examined TAAs.

\begin{tabular}{|c|c|c|c|c|}
\hline $\begin{array}{l}\text { Antigen } \\
\text { name }\end{array}$ & $\begin{array}{l}\text { Accession } \\
\text { no. }\end{array}$ & Primers & $\begin{array}{l}\text { Melting } \\
\text { temp. }\left({ }^{\circ} \mathrm{C}\right)\end{array}$ & $\begin{array}{l}\text { No. of } \\
\text { cycles }\end{array}$ \\
\hline BAGE & NM_001187.1 & $\begin{array}{l}\text { F: 5'-TGG CTC GTC TCA CTC TGG-3' } \\
\text { R: 5'-CCT CCT ATT GCT CCT GTT G-3' }\end{array}$ & 64 & 35 \\
\hline G250 (CA9) & NM_0011216.1 & $\begin{array}{l}\text { F: 5'-ACT GCT GCT TCT GAT GCC TGT-3' } \\
\text { R: 5'-AGT TCT GGG AGC GGC GGG A-3' }\end{array}$ & 68 & 35 \\
\hline hTERT & NM_003219.1 & $\begin{array}{l}\text { F: 5'-CCT CTG TGC TGG GCC TGG ACG ATA-3' } \\
\text { R: 5'-ACG GCT GGA GGT CTG TCA AGG TAG-3' }\end{array}$ & 68 & 35 \\
\hline MAZ & NM_002383.1 & $\begin{array}{l}\text { F: 5'-CCT TCC GCG ACG TCT ACC ACC TGA-3' } \\
\text { R: 5'-CTA CTG CTG CCG CTG CCG CTG-3' }\end{array}$ & 68 & 32 \\
\hline MPP11 & X_98260 & $\begin{array}{l}\text { F: 5'-AAG ATC ATT ATG CAG TTC TTG GAC-3' } \\
\text { R: 5'-CCA ATA ACA TCT TTG GCA GTT CT-3' }\end{array}$ & 60 & 35 \\
\hline NY-ESO-1 & NM_139250 & $\begin{array}{l}\text { F: 5'-ATG GAT GCT GCA GAT GCG G-3' } \\
\text { R: 5'-GGC TTA GCG CCT CTG CCC TG-3' }\end{array}$ & 60 & 35 \\
\hline NY-Ren60 & NM_032582.2 & $\begin{array}{l}\text { F: 5'-GAA TCG CCC CAG CCT CTT TG-3' } \\
\text { R: 5'-ACT CTG CGC ATC CAC TTT CTT CAG-3' }\end{array}$ & 58 & 30 \\
\hline PINCH & NM_004987.2 & $\begin{array}{l}\text { F: 5'-GCC AAC TGC GGG AAG GAG-3' } \\
\text { R: 5'-GGA AGC AAA CAT CAC CAA ATA-3' }\end{array}$ & 56 & 32 \\
\hline PRAME & NM_006115 & $\begin{array}{l}\text { F: 5'-GTC CTG AGG CCA GCC TAA GT-3' } \\
\text { R: 5'-GGA GAG GAG GAG TCT ACG CA-3' }\end{array}$ & 64 & 35 \\
\hline Proteinase 3 & NM_002777.2 & $\begin{array}{l}\text { F: 5'-ACC TCA GTC CAG CTG CCA-3' } \\
\text { R: 5'-GAA AGT GCA AAT GTT ATG-3' }\end{array}$ & 52 & 35 \\
\hline RHAMM & NM_012484.1 & $\begin{array}{l}\text { F: 5'-GGA AGC AAG GCT AAA TGC TG -3' } \\
\text { R: 5'-ACC TGC AGC TTC ATC TCC AT-3' }\end{array}$ & 66 & 35 \\
\hline $\begin{array}{l}\text { RHAMM/ } \\
\text { RHAMM-exon } 4^{-1}\end{array}$ & NM_012484.1 & $\begin{array}{l}\text { F: 5'-GGC CGT CAA CAT GTC CTT TCC TA-3' } \\
\text { R: 5'-TTG GGC TAT TTT CCC TTG AGA CTC-3' }\end{array}$ & 68 & 35 \\
\hline Fibromodulin & NM_002023.2 & $\begin{array}{l}\text { F: 5'-CAA CAC CTT CAA TTC CAG CA-3' } \\
\text { R: 5'-ACC TGC AGC TGG GAG AAG T-3' }\end{array}$ & 55 & 35 \\
\hline Syntaxin & NM_004604.2 & $\begin{array}{l}\text { F: 5'-CAG TGG GCA AAG CGA GGT GTT-3' } \\
\text { R: 5'-ACT GTG ACG CCA ATG ATG ACT GCT-3' }\end{array}$ & 58 & 30 \\
\hline WT-1 & NM_000378.2 & $\begin{array}{l}\text { F: 5'-ATG AGG ATC CCA TGG GCC AGC A-3' } \\
\text { R: 5'-CCT GGG ACA CTG AAC GGT CCC CGA-3' }\end{array}$ & 64 & 35 \\
\hline HSJ & NM_008298.1 & $\begin{array}{l}\text { F: 5'-AGG AGC AGT AGA GTG CTG TC-3' } \\
\text { R: 5'-GAC AGC ACT CTA CTG CTC CT-3' }\end{array}$ & 56 & 35 \\
\hline OFAiLRP & J_03799 & $\begin{array}{l}\text { F: 5'-ATG TCC GGA GCC CTT GAT GTC CTG CAA ATG-3' } \\
\text { R: 5'-TTA AGA CCA GTC AGT GGT TGC TCC TAC CC-3' }\end{array}$ & 68 & 35 \\
\hline Survivin & AF077350 & $\begin{array}{l}\text { F: 5'-CGA CCC CAT AGA GGA ACA TAA A-3' } \\
\text { R: 5'-GGA ATA AAC CCT GGA AGT GGT G-3' }\end{array}$ & 59 & 30 \\
\hline B-actin & XM_037235 & $\begin{array}{l}\text { F: 5'-GCA TCG TGA TGG ACT CCG-3' } \\
\text { R: 5'-GCT GGA AGG TGG ACA GCG A-3' }\end{array}$ & 68 & 24 \\
\hline TBP & NM_003194.2 & $\begin{array}{l}\text { F: 5'-CAC GAA CCA CGG CAC TGA TT-3' } \\
\text { R: 5'-TTT TCT TGC TGC CAG TCT GGA C-3' }\end{array}$ & 60 & 40 \\
\hline
\end{tabular}

F, forward; R, reverse. 


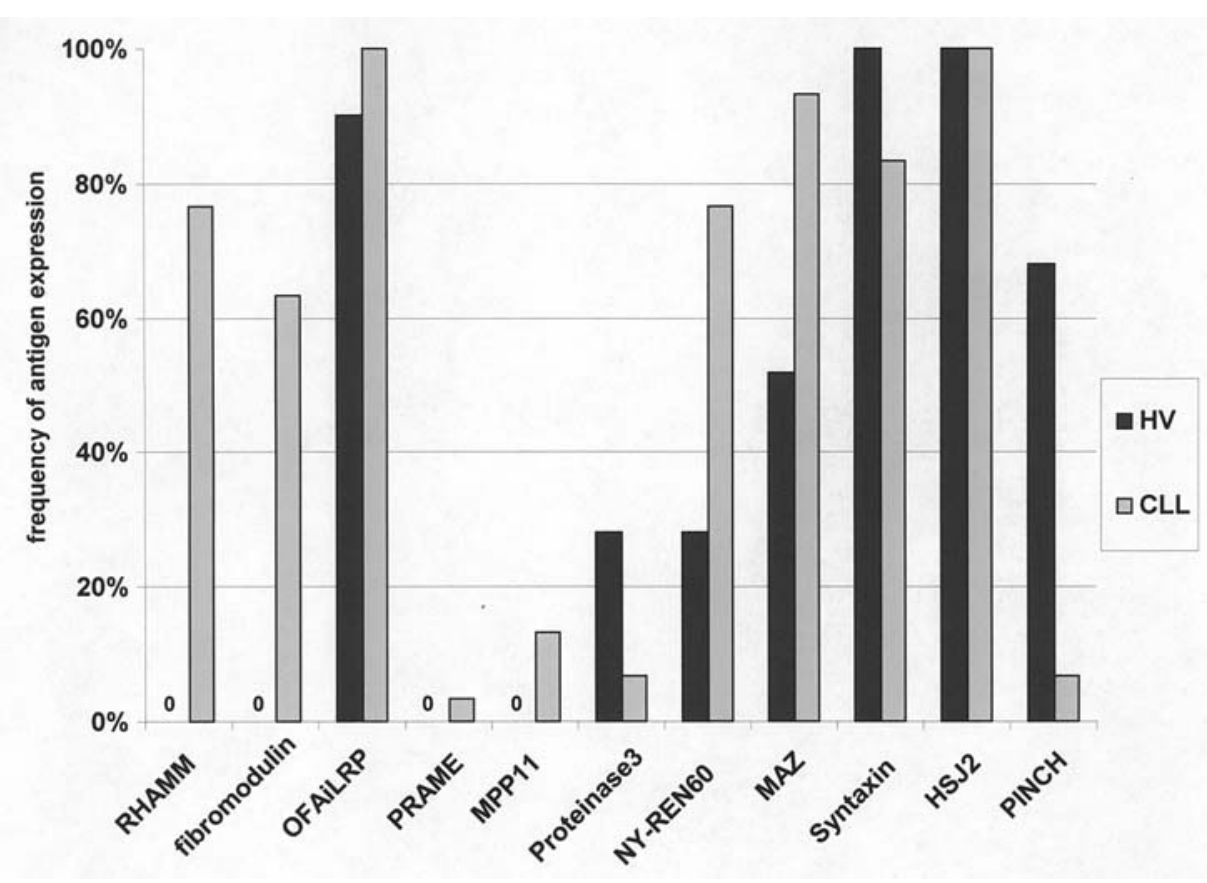

Figure 1. Expression of selected TAAs in B-CLL patients versus healthy volunteers (HV). The frequency of antigen expression in 30 B-CLL patients and 20 healthy volunteers (HV) was assessed by conventional RT-PCR as described in Materials and methods.

were thawed with a yield of $>90 \%$ viable cells and subsequently selected by magnetic beads through a MACS column (Miltenyi Biotec). More than $95 \%$ purity was reached in the $\mathrm{CD}^{+}$fraction. CD8-negative antigen presenting cells (APCs) were irradiated with $30 \mathrm{~Gy}$ and pulsed with a RHAMM/CD168-derived peptide or a control peptide at a concentration of $20 \mu \mathrm{g} / \mathrm{ml}$ for $2 \mathrm{~h}$. After co-incubation with CD8-positive T lymphocytes overnight, the MLPC was supplemented with $10 \mathrm{U} / \mathrm{ml}$ IL-2 (human interleukin-2, Sigma-Aldrich, Munich, Germany) and $20 \mathrm{ng} / \mathrm{ml}$ IL-7 (recombinant, human interleukin-7; Strathmann Biotec AG, Hamburg, Germany) on day +1 . On day +7 , the medium was changed and new irradiated and peptide-pulsed CD8-negative APCs were added as 1 week before. Again, the MLPC was supplemented with IL-2 and IL-7.

After a total of 16 days of culture, T-cells were harvested and evaluated for their specific cytotoxicity in a standard ELISPOT assay against T2-cells pulsed with the RHAMM/ CD168 peptide, with the positive control IMP peptide, with unspecific positive control Pokeweed mitogen (PWM) (SigmaAldrich) or without peptide, as described earlier (15).

Interferon (IFN)- $\gamma$ and granzyme B ELISPOT assay. IFN- $\gamma$ and granzyme B ELISPOT assays were performed as described elsewhere $(21,26)$ to determine specific lysis of RHAMM/ CD168 (peptide)-positive target cells according to the manufacturer's instructions (BD, San Diego, USA).

Tetramer staining. CD8 ${ }^{+} \mathrm{T}$-cells $\left(1 \times 10^{6}\right)$, stimulated with irradiated CD8-negative antigen presenting cells in the presence of R3 peptide or an irrelevant peptide, MAGE3-derived peptide (FLWGPRALV), were stained with the tetramer, HLA-A2/ $\mathrm{R} 3 * \mathrm{PE}$ (Ludwig Institute for Cancer Research, Lausanne, Switzerland), at a concentration of $5 \mu \mathrm{g} / \mathrm{ml}$ and anti-CCR7 pure rat antibody (BD, Heidelberg, Germany) in the dark and incubated for $40 \mathrm{~min}$ at room temperature. Thereafter, antiCD8*PerCP (BD), anti-CD45RA*FITC (BD) and secondary antibody goat anti-rat IgG*APC (Caltag Laboratories) were added at $4^{\circ} \mathrm{C}$ for $20 \mathrm{~min}$ in the dark. After washing twice, stained cells were analyzed by flow cytometry.

\section{Results}

Differential mRNA expression of TAAs in B-CLL patients versus healthy volunteers. The mRNA expression of different immunogenic antigens was evaluated in PBMCs from 30 B-CLL patients. Several antigens with expression in other leukemia types (AML, CML and the cell line, K562) showed no mRNA expression in naive B-CLL samples: WT-1, MAGE A1, BAGE, G250, hTERT and survivin.

A frequency of $<20 \%$ in B-CLL patients was noted for the mRNA expression of MPP11, PINCH, PRAME and proteinase 3. MPP11 was detected in $13 \%$ of B-CLL patients, PINCH in $7 \%$, PRAME in $3 \%$ and proteinase 3 in $7 \%$ of these patients. More than half of the examined B-CLL patients showed positive mRNA expression for RHAMM/ RHAMM $^{\text {-exon } 4}(77 \%)$, fibromodulin $(63 \%)$, NY-Ren60 (77\%) and syntaxin $(83 \%)$. The highest frequencies of mRNA expression in B-CLL patients were detected for HSJ2 (100\%), MAZ (93\%) and OFAiLRP (100\%). Only RHAMM/CD168, fibromodulin, PRAME and MPP11 showed expression in B-CLL patients, but not in HV. Fig. 1 gives a comparison of the mRNA expression frequencies of TAAs in B-CLL patients versus healthy volunteers.

RHAMM/CD168 mRNA expression in different stages of B-CLL by conventional $R T-P C R$. RHAMM/RHAMM ${ }^{\text {-exon } 4}$ is more frequently expressed in advanced stages of disease according 


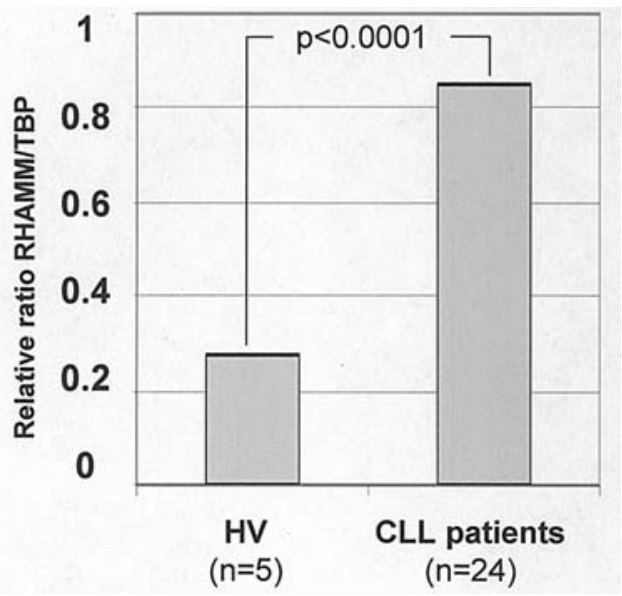

Figure 2. The relative ratio of RHAMM/TBP in early stages of B-CLL patients as assessed by LightCycler real-time RT-PCR. Quantitative results obtained by LightCycler 'real-time' RT-PCR for RHAMM/CD168 and for TATAbinding protein (TBP were transformed into copy numbers, and the relative ratio of RHAMM/TBP was calculated). The graphic displays the difference of RHAMM/CD168 quantity in 24 patients with early stages of B-CLL versus 5 healthy volunteers (HVs).

to Rai (3 and 4) than in early stages (0-2) according to Rai ( $100 \%$ versus $61 \%, \mathrm{p}=0.014)$.

Expression analysis of RHAMM by real-time RT-PCR. The results obtained by quantitative measurement of mRNA by real-time RT-PCR for RHAMM from 24 patients with B-CLL were transformed into copy numbers and then the percentage of TBP was calculated. Two-tailed p-value of the alternative t-test was highly significant $(\mathrm{p}<0.0001)$ (Fig. 2). No significant difference $(\mathrm{p}=0.38)$ in higher relative expression of RHAMM/ CD168 between B-CLL patients in stage 0 and 1 according to Rai was noted. No RHAMM/CD168 expression was detected in B-cells isolated by MACS column separation from PBMCs of 5 healthy donors.

The relative ratio of $R H A M M / T B P$ differs insignificantly in ZAP-70-positive and -negative B-CLL patients. In ZAP-70positive B-CLL patients the mean relative RHAMM/CD168 level (average, 0.92; SD, 0.52; range, 0.36-1.91; $\mathrm{n}=9$ ) did not significantly differ $(\mathrm{p}=0.23)$ from the results obtained in the ZAP-70-negative group (average, 0.67; SD, 0.37; range, $0.34-1.53 ; \mathrm{n}=12)$.

Mixed lymphocyte peptide cultures and ELISPOT. In ELISPOT assays for INF- $\gamma$ and granzyme B, no or only slight ( $<10$ spots/40,000 CD8 ${ }^{+}$cells) CTL responses even against IMP were observed in 4 CLL patients after 8 days of culture (data not shown). For 6 other CLL patients, we prolonged the stimulation time. After 16 days of culture, CTL responses by specific secretion of granzyme B and IFN- $\gamma$ against the RHAMM/CD168-derived peptide, R3, and to a lesser extent against the IMP peptide, as well as strong unspecific T-cell stimulation by the lectin, PWM, was observed in 3/6 of our CLL patients (Fig. 3).

Tetramer staining of $C D 8^{+}$T lymphocytes specifically recognizing peptide $R 3$ in the context of $H L A-A 2 . \mathrm{CD}^{+}$ lymphocytes from 3 other CLL patients were subjected to two rounds of stimulation with autologous CD8- APCs in the presence of the R3 peptide or in the presence of the irrelevant MAGE3 derived peptide. FACS analysis with four colours revealed a frequency of $\mathrm{CD}^{+} \mathrm{T}$-cells specifically recognizing the R3 peptide ranging from 0.2 to $2.2 \%$ in the presence of the R3 peptide (Fig. 4D) in contrast with $0.01-0.3 \%$ in the presence of the irrelevant peptide MAGE3 (Fig. 4C). CD8+HLA-A2/ R3tetramer ${ }^{+} \mathrm{T}$ lymphocytes elicited by stimulation through the R3 peptide were gated (R2 gate) and further characterized as predominantly $(62 \%)$ CCR7-CD45RA ${ }^{\text {high }}$ effector T-cells (Fig. 4E).

\section{Discussion}

Vaccination strategies for patients with B-CLL using whole tumor lysates (27), irradiated cells or total RNA to induce anti-tumor immune responses are under current clinical investigation (8). These immunotherapeutical approaches circumvent the definition of specific antigens. However, to reach a high concentration of $\mathrm{T}$-cell epitope peptide and to induce thereby a clinically relevant $\mathrm{T}$-cell response, the definition of immunogenic TAAs and their T-cell epitopes in B-CLL is highly desirable. Vaccination with antigen peptides might allow a straightforward assessment of T-cell responses to these particular peptides. Further clinical use of immunotherapy in CLL might be combined with chemotherapy utilizing novel pharmacological agents (28), as some of them affect T-cell function only at high concentrations.

In this study, we found several expression patterns of TAAs in B-CLL patients versus healthy donors (HVs), some TAAs showed exquisite expression in leukemia but not normal cells. Tumor-restricted expression would be favourable for future immunotherapies because of the absence of danger to induce autoimmune reactions by vaccination of patients with these TAAs.

High frequencies of tumor-restricted antigens such as RHAMM/CD168 and fibromodulin (60-80\%) and lower $(<20 \%)$ expression frequencies of PRAME and MPP11 were noted. Interestingly, no expression of hTERT and survivin was observed. Tchirkov et al (29) noted an increased hTERT expression in advanced stages of B-CLL and, in opposition to others (30), proposed hTERT to be a prognostic marker in B-CLL. However, the mean telomere length of PBMCs from B-CLL patients was comparable to the length observed in HVs (31).

Survivin, a member of the inhibitors of apoptosis gene family (32) and also a protein involved in the regulation of mitosis (33) is overexpressed in bone marrow (34) and lymph nodes (detected only in pseudofollicules) from patients with B-CLL (35). It is expressed on CD40L stimulated CLL cells $(35,36)$, but not on non-stimulated CLL cells on the protein level (17). This might be the reason why we were not able to detect an mRNA signal for survivin in the PBMCs of B-CLL patients in this study, who were mainly in an early stage of the disease.

T-cells isolated from PBMCs of B-CLL patients were demonstrated in vitro to be reactive against OFAiLRP-derived peptide pulsed DCs (20). The results of the present study suggest that OFAiLRP might not be the best target for 


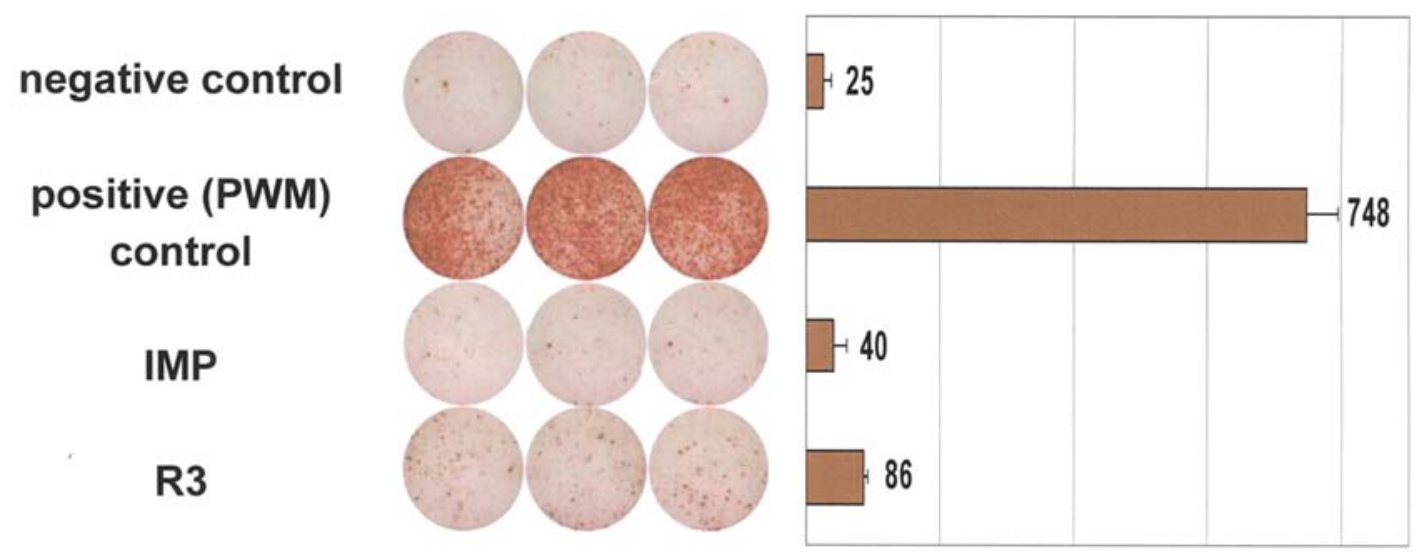

Figure 3. Specific CTL responses against RHAMM/CD168 in one selected B-CLL patient (patient 27) after 16 days of MLPC (as assessed by ELISPOT assay for granzyme B, numbers indicate the mean value of spots in triplicate per 40,000 CD8+ cells). After 16 days of culture, T-cells were harvested and evaluated for their specific cytotoxicity in production of granzyme B in assay against T2-cells pulsed with the RHAMM/CD168 R3 peptide, with the influenza matrix protein (IMP) peptide as a peptide-specific control, with the lectin Pokeweed mitogen (PWM) as positive control or without peptide as a negative control. Results were evaluated by the use of an ELISPOT reader consisting of a video camera and a computer system with pattern recognition software.

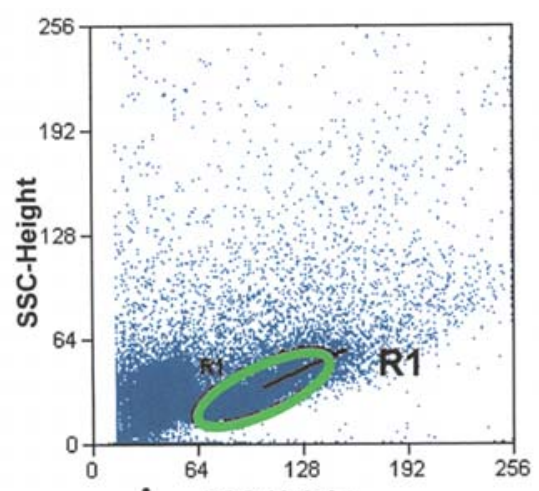

A FSC-Height

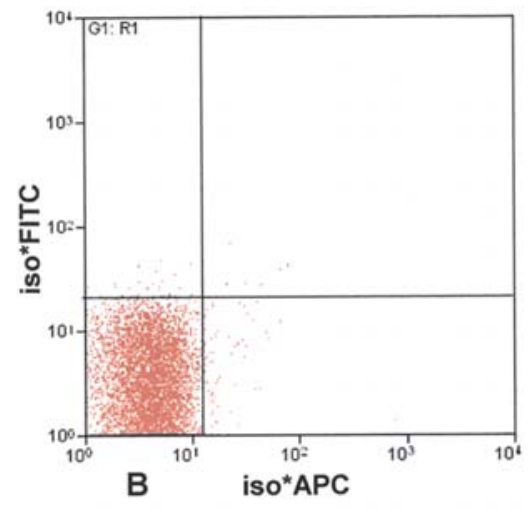

B

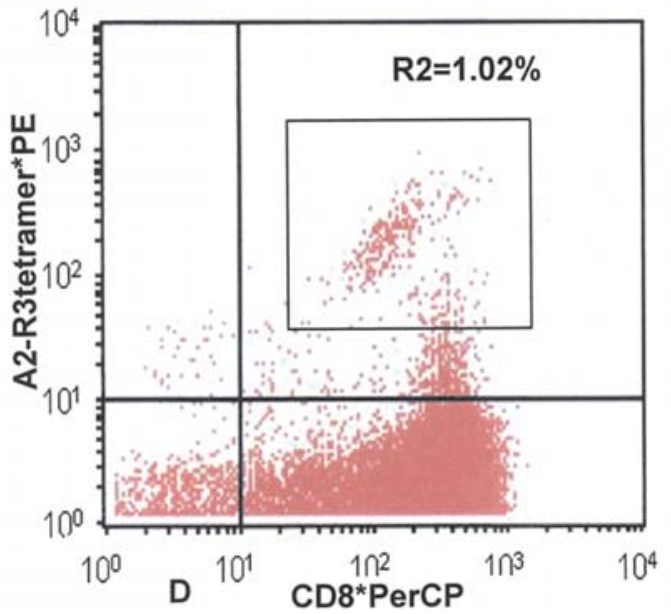

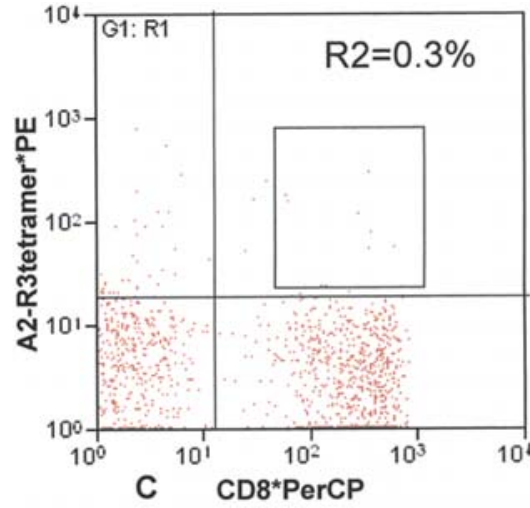

C $\quad$ CD8*PerCP

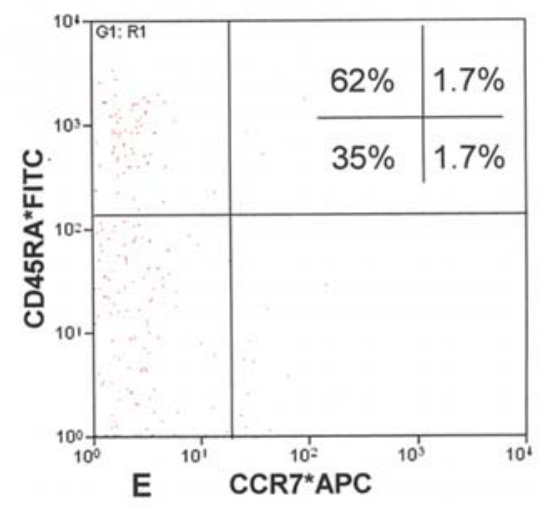

Figure 4. Four-color staining of R3-specific T lymphocytes. CD8+ lymphocytes from a CLL patient (patient 41) were subjected to two rounds of stimulation with autologous CD8-APCs in the presence of the R3 peptide (D) as described in Materials and methods. The figure displays representative results using fourcolor staining of CD8 and HLA-A2/R3 tetramer peptide. A difference in frequency of R3-specific T-cells was noted. The lymphocytes (gated in R1 of A) were gated as double positive for $\mathrm{CD} 8^{+}$and HLA-A2/R3 tetramer (+) (gate R2 of D) and further characterized by counterstaining for CCR7 and CD45RA (E). The majority of the T-cells were revealed to be CD8 ${ }^{+} \mathrm{HLA}-\mathrm{A} 2 / \mathrm{R} 3$ tetramer ${ }^{+} \mathrm{CCR} 7-\mathrm{CD} 45 \mathrm{R} \mathrm{A}^{\text {high }}$ effector T-cells (as compared with iso-control in B). Control tetramer staining revealed up to $0.3 \%$ non-specific $\mathrm{CD} 8^{+}$cells stained with HLA-A2/R3tetramer ${ }^{+} \mathrm{CD} 8^{+} \mathrm{T}$-cells after stimulation with the irrelevant peptide, MAGE3 (C),

immunotherapy because of its strong expression on PBMCs from HVs, indicating the potential danger of autoimmune reactions. However, we did not consider protein expression, post-translational changes and the difference between the monomeric immature and the dimerized mature form of LRP (37). Siegel et al (20) did not observe CTL responses against bone marrow and $\mathrm{CD} 34^{+}$from healthy individuals by T-cells stimulated with DC transfected with OFAiLRP. 
Based on gene expression profiling data (38), fibromodulin was recently proposed to be a novel TAA in B-CLL. CTL responses were detected against four different HLA-A2 binding fibromodulin-derived peptides (19). Fibromodulin is expressed on normal connective tissue, binds collagen fibres (39) and is involved in wound repair (40). Therefore, vaccination with fibromodulin protein or peptide might induce autoimmune reactions.

The most interesting finding of this study was the definition of RHAMM/CD168, a new promising TAA candidate in B-CLL patients, which is expressed on tumor cells but neither in PBMCs nor in CD34+ cells from healthy donors $(11,26)$ (Fig. 1). RHAMM have restricted expression pattern to thymus and testis and is not expressed on healthy B-cells (11; data not shown), which indicates a limited risk of autoimmunity when RHAMM/CD168 is used as a target for immunotherapy. An increased CTL response against a RHAMM/CD168derived peptide was observed after vaccinations with DCs pulsed with CLL cell lysate (27). RHAMM/CD168 was first described as a molecule required for cell motility and cell cycle progression through the $\mathrm{G} 2$ and $\mathrm{M}$ phase (41). RHAMM/CD168 plays an essential role in the organization and maintenance of mitotic spindle apparatus and strongly activates extracellular-regulated kinase (erk1) $(42,43)$. RHAMM/CD168 was found to be overexpressed in multiple myeloma $(\mathrm{MM})$ and breast cancer $(44,45)$. Overexpression of RHAMM/CD168 is essential for ras-mediated transformation (46).

Expression of RHAMM/CD168 on the mRNA level and protein level in a limited number of CLL patients (3 and 6 respectively) was noted previously $(41,47)$, in contrast to other results describing weak expression of RHAMM on protein level (44).

Here, we show that RHAMM/CD168 is expressed in all stages of the examined B-CLL patients with increasing frequencies in more advanced stages. In colon cancer and CML, high RHAMM/CD168 expression is associated with metastases and higher tumor stages $(18,48)$.

We assessed the level of RHAMM/CD168 expression in patients with early stages of B-CLL, presuming that these patients might potentially profit from immunotherapy.

Besides the status of $\operatorname{IgVH}$ mutation (49), the $\zeta$ associated protein 70 (ZAP-70) was found to be a strong prognostic factor in B-CLL patients (24). In the present study, RHAMM/ CD168 was expressed in both ZAP-70-positive and -negative B-CLL patients.

In some B-CLL patients, spontaneously occurring leukaemia-specific T-cells recognizing LAAs were more frequently noted at an indolent stage rather than in progressive disease (50). Here, we noted a severe impairment of T-cell function, a fact demonstrated also by other groups (5), in several B-CLL patients evaluated in this work. No T-cell reactivity to an unspecific stimulus, e.g. a lectin such as Pokeweed mitogen (PWM), was observed in a mixed lymphocyte reaction after single presensitization. The impaired T-cell reactivity in B-CLL patients might be explained by the influence of $\mathrm{CD} 19^{+} / \mathrm{CD}^{+}$leukemic cells or T regulatory cells on T-cell function as well as on the DC population $(5,51)$ and might be overcome by specific adjuvants, such as IL-12, IL-15 or SCD40L $(52,53)$. After 2 weeks of presensitization, we observed $\mathrm{CD}^{+}{ }^{+} \mathrm{T}$-cells reactive to PWM, IMP peptide or RHAMM/CD168 peptide in another cohort of B-CLL patients (Figs. 3 and 4). The lysis of tumor cells by activated IFN- $\gamma$ producing $\mathrm{T}$ lymphocytes through granzyme B plays a main role in tumor rejection (54). In our experiments, we induced IFN- $\gamma$ and granzyme B secreting CD8 ${ }^{+}$T-cells which were able to recognize $\mathrm{T} 2$-cells pulsed with the $\mathrm{R} 3$ peptide in vitro. $\mathrm{By}$ tetramer staining, we further characterized these R3-specific T-cells as CD8 ${ }^{+}$HLA-A2/R3tetramer ${ }^{+}$CCR7-CD45RA ${ }^{\text {high }}$ effector T-cells (data not shown).

In summary, we demonstrated high expression frequencies of the leukemia-specific antigen, RHAMM/CD168, and fibromodulin in patients with B-CLL. RHAMM/CD168 expression occurred with no respect to the ZAP-70 status. In a subgroup of CLL patients, we detected $\mathrm{CD} 8^{+}$effector T-cells isolated from PBMCs reactive to a RHAMM/CD168 T-cell epitope. We conclude that vaccination with RHAMM/CD168 might be an interesting clinical approach for some patients with B-CLL, especially in early stages of disease as T-cell function is still preserved and the tumor load is rather limited.

\section{Acknowledgements}

We would like to thank Ms. Anita Szmaragowska and Ms. Marlies Götz for their excellent technical support in this study. K.G. was supported by grants from the German Academic Exchange Service (DAAD) and Catholic Academic Exchange Service (KAAD).

\section{References}

1. Keating MJ, Chiorazzi N, Messmer B, et al: Biology and treatment of chronic lymphocytic leukemia. Hematology (ASH Educational Program) pp153-175, 2003.

2. Jäger E, Jäger D and Knuth A: Antigen-specific immunotherapy and cancer vaccines. Int J Cancer 106: 817-820, 2003.

3. Goldman D: Chronic lymphocytic leukemia and its impact on the immune system. Clin J Oncol Nurs 4: 233-236, 2000.

4. Tsiodras S, Samonis G, Keating MJ and Kontoyiannis DP: Infection and immunity in chronic lymphocytic leukemia. Mayo Clin Proc 75: 1039-1054, 2000.

5. Scrivener S, Goddard RV, Kaminski ER and Prentice AG: Abnormal T-cell function in B-cell chronic lymphocytic leukaemia. Leuk Lymphoma 44: 383-389, 2003.

6. Orsini E, Guarini A, Chiaretti S, Mauro FR and Foa R: The circulating dendritic cell compartment in patients with chronic lymphocytic leukemia is severely defective and unable to stimulate an effective T-cell response. Cancer Res 63: 4497-4506, 2003.

7. Harig S, Witzens M, Krackhardt AM, et al: Induction of cytotoxic T-cell responses against immunoglobulin $\mathrm{V}$ region-derived peptides modified at human leukocyte antigen-A2 binding residues. Blood 98: 2999-3005, 2001.

8. Müller MR, Tsakou G, Grünebach F, Schmidt SM and Brossart P: Induction of chronic lymphocytic leukemia (CLL)-specific CD4and CD8-mediated T-cell responses using RNA-transfected dendritic cells. Blood 103: 1763-1769, 2004.

9. Marks DI, Lush R, Cavenagh J, et al: The toxicity and efficacy of donor lymphocyte infusions given after reduced-intensity conditioning allogeneic stem cell transplantation. Blood 100: 3108-3114, 2002.

10. Ritgen M, Stilgenbauer S, von Neuhoff N, et al: Graft-versusleukemia activity may overcome therapeutic resistance of chronic lymphocytic leukemia with unmutated immunoglobulin variable heavy-chain gene status: implications of minimal residual disease measurement with quantitative PCR. Blood 104: 2600-2602, 2004

11. Greiner J, Ringhoffer M, Taniguchi M, et al: RHAMM is a new immunogenic tumor-associated antigen overexpressed in acute and chronic myeloid leukemia. Exp J Hematol 30: 1029-1035, 2002. 
12. Greiner J, Ringhoffer M, Taniguchi M, Schmitt A, Döhner H and Schmitt M: Characterization of several leukemia-associated antigens inducing humoral immune responses in acute and chronic myeloid leukemia (AML/CML). Int J Cancer 106: 224-231, 2003.

13. Kessler JH, Beekman NJ, Bres-Vloemans SA, et al: Efficient identification of novel HLA-A 0201-presented cytotoxic T lymphocyte epitopes in the widely expressed tumor antigen PRAME by proteasome-mediated digestion analysis. J Exp Med 193: 73-88, 2001.

14. Maurer U, Weidmann E, Karakas T, Hoelzer D and Bergmann L: Wilms tumor gene (wt1) mRNA is equally expressed in blast cells from acute myeloid leukemia and normal CD $34^{+}$progenitors. Blood 90: 4230-4232, 1997.

15. Scheibenbogen C, Letsch A, Thiel E, et al: CD8 T-cell responses to Wilms tumor gene product WT1 and proteinase 3 in patients with acute myeloid leukemia. Blood 100: 2132-2137, 2002.

16. Andersen MH, Pedersen L $\varnothing$, Becker JC and Straten P: Identification of a cytotoxic $\mathrm{T}$ lymphocyte response to the apoptosis inhibitor protein survivin in cancer patients. Cancer Res 61: 869-872, 2000.

17. Zeis M, Siegel S, Wagner A, et al: Generation of cytotoxic responses in mice and human individuals against hematological malignancies using survivin-RNA-transfected dendritic cells. J Immunol 170: 5391-5397, 2003.

18. Schmidt SM, Schag K, Müller MR, et al: Survivin is a shared tumor-associated antigen expressed in a broad variety of malignancies and recognized by specific cytotoxic $\mathrm{T}$ cells. Blood 102: 571-576, 2003.

19. Mayr C, Bund D, Schlee M, et al: Fibromodulin as a novel tumor-associated antigen (TAA) in chronic lymphocytic leukemia (CLL) which allows expansion of specific CD $8^{+}$autologous $\mathrm{T}$ lymphocytes. Blood 105: 1566-1573, 2005.

20. Siegel S, Wagner A, Kabelitz D, et al: Induction of cytotoxic $\mathrm{T}$-cell responses against the oncofetal antigen-immature laminin receptor for the treatment of hematologic malignancies. Blood 102: 4416-4423, 2003.

21. Greiner J, Ringhoffer M, Simikopinko O, et al: Simultaneous expression of different immunogenic antigens in acute myeloid leukemia. Exp Hematol 28: 1413-1422, 2000.

22. Scanlan MJ, Gordan JD, Williamson B, et al: Antigens recognized by autologous antibody in patients with renal-cell carcinoma. Int J Cancer 83: 456-464, 1999.

23. Bojarska-Junak A, Rolinski J and Kawiak J: Modification of immunocytochemical ZAP-70 assay for potential clinical application in B-cell chronic lymphocytic leukemia. Folia Histochem Cytobiol 45: 19-23, 2005.

24. Crespo M, Bosch F, Villamor N, et al: ZAP-70 expression as a surrogate for immunoglobulin-variable-region mutations in chronic lymphocytic leukemia. N Engl J Med 348: 1764-1775, 2003.

25. Rammensee HG, Bachmann J, Emmerich NN, Bachor OA and Stevanovic S: SYFPEITHI: database for MHC ligands and peptide motifs. Immunogenetics 50: 213, 1999 (access via: http:// www.syfpeithi.de).

26. Greiner J, Li L, Ringhoffer M, Barth TFE, et al: Identification and characterization of epitopes of the receptor for hyaluronic acid mediated motility (RHAMM/CD168) recognized by CD8 positive T cells of HLA-A2 positive patients with acute myeloid leukemia. Blood 106: 938-945, 2005.

27. Hus I, Rolinski J, Tabarkiewicz J, et al: Allogeneic dendritic cells pulsed with tumor lysates or apoptotic bodies as immunotherapy for patients with early-stage B-cell chronic lymphocytic leukemia. Leukemia (Epub ahead of print), 2005.

28. Bruserud O, Tronstad KJ, McCormack E and Gjertsen BT: Is targeted chemotherapy an alternative to immunotherapy in chronic lymphocytic leukemia? Cancer Immunol Immunother $1-8,2005$ (Epub ahead of print).

29. Tchirkov A, Chaleteix C, Magnac C, et al: hTERT expression and prognosis in B-chronic lymphocytic leukemia. Ann Oncol 15: 1476-1480, 2004

30. Verstovsek S, Giles FJ, O'Brien S, et al: Telomerase activity is not a prognostic factor in chronic lymphocytic leukemia. Leuk Res 28: 707-711, 2004.

31. Damle RN, Batliwalla FM, Ghiotto F, et al: Telomere length and telomerase activity delineate distinctive replicative features of the B-CLL subgroups defined by immunoglobulin $\mathrm{V}$ gene mutations. Blood 103: 375-382, 2004.

32. Ambrosini G, Adida C and Altieri DC: A novel anti-apoptosis gene, survivin, expressed in cancer and lymphoma. Nat Med 3: 917-921, 1997.
33. Caldas H, Jiang Y, Holloway MP, et al: Survivin splice variants regulate the balance between proliferation and cell death. Oncogene 24: 1994-2007, 2005.

34. Nakagawa Y, Yamaguchi S, Hasegawa M, et al: Differential expression of survivin in bone marrow cells from patients with acute lymphocytic leukemia and chronic lymphocytic leukemia. Leuk Res 28: 487-494, 2004.

35. Granziero L, Ghia P, Circosta P, et al: Survivin is expressed on CD40 stimulation and interfaces proliferation and apoptosis in B-cell chronic lymphocytic leukemia. Blood 97: 2777-2783, 2001.

36. Giannopoulos K, Dmoszynska A, Rolinski J, Hus I and Schmitt M: The expression of survivin in patients with B-cell chronic lymphocytic leukemia (B-CLL). Acta Haemat Pol 36: 83-88, 2005

37. Gauczynski S, Peyrin JM, Haik S, et al: The $37-\mathrm{kDa} / 67-\mathrm{kDa}$ laminin receptor acts as the cell-surface receptor for the cellular prion protein. EMBO J 20: 5863-5875, 2001 .

38. Klein U, Tu Y, Stolovitzky GA, Mattioli M, et al: Gene expression profiling of B cell chronic lymphocytic leukemia reveals a homogeneous phenotype related to memory B cells. J Exp Med 194: 1625-1638, 2001.

39. Hedbom E and Heinegard D: Binding of fibromodulin and decorin to separate sites on fibrillar collagens. J Biol Chem 268: 27307-27312, 1993 .

40. Hakkinen L, Westermarck J, Kahari VM and Larjava H: Human granulation-tissue fibroblasts show enhanced proteoglycan gene expression and altered response to TGF-beta 1. J Dent Res 75: 1767-1778, 1996.

41. Turley EA, Belch AR, Poppema S and Pilarski LM: Expression and function of a receptor of hyaluronan-mediated motility (RHAMM) on normal and malignant B lymphocytes. Blood 81: 446-453, 1993.

42. Assmann V, Jenkinson D, Marshall JF and Hart IR: The intracellular hyaluronan receptor RHAMM/IHABP interacts with microtubules and actin filaments. J Cell Sci 112: 3943-3954, 1999.

43. Zhang S, Chang MCY, Zylka D, Turley S, Harrison R and Turley EA: The hyaluronan receptor RHAMM regulates extracellular-regulated kinase. J Biol Chem 273: 11342-11348, 1998.

44. Craine M, Belch AR, Mant MJ and Pilarski L: Overexpression of the receptor for hyaluronan-mediated motility (RHAMM) characterizes the malignant clones in multiple myeloma: identification of three distinct RHAMM variants. Blood 93: 1684-1696, 1999.

45. Assmann V, Marshal JF, Fieber C, Hofmann M and Hart IR: The human hyaluronan receptor RHAMM is expressed as an intracellular protein in breast cancer cells. J Cell Sci 111: 1685-1694, 1998.

46. Hall CL, Yang B, Yang X, et al: Overexpression of the hyaluronan receptor RHAMM is transforming and is also required for H-ras transformation. Cell 82: 19-26, 1995.

47. Till KJ, Zuzel M and Cawley JC: The role of hyaluronan and interleukin 8 in the migration of chronic lymphocytic leukemia cells within lymphoreticular tissues. Cancer Res 59: 4419-4426, 1999.

48. Yamada $\mathrm{Y}$, Itano N, Narimatsu H, et al: Receptor for hyaluronanmediated motility and CD44 expressions in colon cancer assessed by quantitative analysis using real-time reverse transcriptasepolymerase chain reaction. Jpn J Cancer Res 90: 987-992, 1999.

49. Kröber A, Seiler T, Benner A, et al: V(H) mutation status, CD38 expression level, genomic aberrations, and survival in chronic lymphocytic leukemia. Blood 100: 1410-1416, 2002.

50. Mellstedt $\mathrm{H}$ and Choudhury $\mathrm{A}$ : T and B cells in B-chronic lymphocytic leukaemia: Faust, Mephistopheles and the pact with the Devil. Cancer Immunol Immunother (Epub ahead of print), 2005

51. Orsini E, Pasquale A, Maggio R, et al: Phenotypic and functional characterization of monocyte-derived dendritic cells in chronic lymphocytic leukaemia patients: influence of neoplastic CD19 cells in vivo and in vitro. Br J Haematol 125: 720-728, 2004.

52. Goddard RV, Prentice AG, Copplestone JA and Kaminski ER: In vitro dendritic cell-induced $\mathrm{T}$ cell responses to $\mathrm{B}$ cell chronic lymphocytic leukaemia enhanced by IL-15 and dendritic cellB-CLL electrofusion hybrids. Clin Exp Immunol 131: 82-89, 2003.

53. Von Bergwelt-Baildon M, Maecker B, Schultze J and Gribben JG: CD40 activation: potential for specific immunotherapy in B-CLL. Ann Oncol 15: 853-857, 2004.

54. Russell JH and Ley TJ: Lymphocyte-mediated cytotoxicity. Annu Rev Immunol 20: 323-370, 2002. 